\title{
ENVIRONMENT SCANNING (PEMETAAN LINGKUNGAN) PERUSAHAAN TAMBANG TERHADAP TARAF HIDUP MASYARAKAT SEKITAR
}

\author{
Fretty Welta ${ }^{1}$ (welta18@gmail.com) \\ Lemiyana² (lemiyana@gmail.com) \\ 'Universitas Kader Bangsa Palembang ${ }^{1}$ \\ Universitas Islam Negeri Radaen Fatah Palembang ${ }^{2}$
}

\begin{abstract}
ABSTRAK
Kabupaten Muara Enim yang memiliki potensi sumber daya alam yang melimpah, membuat tertariknya investor yang ingin menamamkan investasi terutama di tambang batubara. Sehingga Permasalahan lingkungan juga semakin menjadi perhatian yang serius, baik oleh konsumen, investor maupun pemerintah. Bagaimanakah Pemetaan Lingkungan perusahaan pertambangan berpengaruh terhadap peningkatan ekonomi masyarakat di lingkungan perusahaan pertambangan. Riset dilakukan di Kecamatan Lawang Kidul Kabupaten Muara Enim, seperti diketahui kawasan Kec. Lawang Kidul memiliki perusahaan pertambangan yang dikelola oleh pihak swasta di bawah pengawasan Pemda setempat. Perusahaan yang ada, diharapkan dampak memberikan kontribusi bagi masyarakat dalam berbagai aspek sosial, budaya, lingkungan, dan ekonomi. Disinilah peran komitmen kuat perusahaan dalam bidang CSR bekerja sama dengan Perguruan Tinggi dalam menciptakan taraf hidup yang lebih baik bagi masyarakat, yang bukan sekedar kepedulian terhadap lingkungan.
\end{abstract}

\section{Kata kunci : Environment Scanning, Tambang, Taraf Hidup}

\section{PENDAHULUAN}

CSR mengandung pengertian yang lebih luas daripada sekedar menyisihkan dana untuk kegiatan sosial. Awalnya CSR memang lebih banyak diwujudkan dalam bentuk karitas dan filantropi perusahaan. Kini mulai ada upaya untuk mendorong agar CSR bergeser dari filantropi menjadi corporate citizenship yang berarti terdapat rekonsiliasi dengan ketertiban sosial dan lebih memberikan kontribusi kepada masyarakat. Dilihat dari asal katanya, CSR berasal dari literatur etika bisnis di Amerika Serikat dikenal sebagai corporate social responsibility atau social responsibility of corporation. Kata corporation atau perusahaan telah dipakai dalam bahasa Indonesia yang diartikan sebagai perusahaan, khususnya perusahaan besar. Dilihat dari asal katanya, "perusahaan" berasal dari bahasa Latin "corpus/ corpora" yang berarti badan.

Dalam sejarah perusahaan dijelaskan bahwa perusahaan itu merupakan suatu badan hukum yang didirikan untuk melayani kepentingan umum (not for profit), namun dalam perkembangannya justeru menumpuk keuntungan (for profit). (Isa 
Wahyudi \& Busyra Azheri, vii). Konsep CSR sendiri sebenarnya bukanlah baru sama sekali, dan pengertiannya tidaklah statis. CSR pertama kali muncul dalam diskursus resmi akademik sejak Howard R Bowen menerbitkan bukunya berjudul Social Responsibilitity of the Businessman pada tahun 1953. Ide dasar CSR yang dikemukakan Bowen mengacu pada kewajiban pelaku bisnis untuk menjalankan usahanya sejalan dengan nilai-nilai dan tujuan yang hendak dicapai masyarakat di tempat perusahaannya beroperasi. Ia menggunakan istilah sejalan dalam konteks itu untuk meyakinkan dunia usaha tentang perlunya mereka memiliki visi yang melampaui kinerja finansial perusahaan. Ia menge-mukakan prinsipprinsip tanggung jawab sosial perusahaan. Prinsip-prinsip yang dikemukakannya mendapat pengakuan publik dan akademisi sehingga Howard $\mathrm{R}$ Bowen dinobatkan sebagai "Bapak CSR". Ada beraneka ragam definisi Corporate Social Responsibility dan sulit diseragamkan. Diantaranya adalah definisi yang dikemukakan oleh Magnan \& Farrel (2004) yang mendefinisikan CSR sebagai "a business acts in socially responsible manner when its decisions and actions account for and balance diverse stakeholder interest.

Menurut Achda (2006), CSR dapat diartikan sebagai komitmen perusahaan untuk mempertanggung jawabkan dampak operasinya dalam dimensi sosial, ekonomi, dan lingkungan, serta terus-menerus menjaga agar dampak tersebut menyumbang manfaat kepada masyarakat dan lingkungan hidupnya. Konsep tanggung jawab sosial perusahaan atau Corporate Social Responsibiliy (CSR), muncul sebagai akibat adanya kenyataan bahwa pada dasarnya karakter alami dari setiap perusahaan adalah mencari keuntungan semaksimal mungkin tanpa memperdulikan kesejahteraan karyawan, masyarakat dan lingkungan alam. Seiring dengan meningkatnya kesadaran dan kepekaan dari stakeholders perusahaan maka konsep tanggung jawab sosial muncul dan menjadi bagian yang tidak terpisahkan dengan kelangsungan hidup perusahaan di masa yang akan datang. Tanggung jawab sosial perusahaan dapat didefinisikan jawab sosial perusahaan dapat didefinisikan secara sederhana sebagai suatu konsep yang mewajibkan perusahan untuk memenuhi dan memperhatikan kepentingan para stakeholder dalam kegiatan operasinya mencari keuntungan. Stakeholder yang dimaksud diantaranya adalah para shareholder, karyawan (buruh), pelanggan, komunitas lokal, pemerintah, lembaga swadaya masyarakat (LSM), dan lain sebagainya. (Jonathan Sofian Lusa, 2007). Tanggung jawab sosial secara lebih sederhana dapat dikatakan sebagai timbal balik perusahaan kepada masyarakat dan lingkungan sekitarnya karena perusahaan telah mengambil keuntungan atas masyarakat dan lingkungan sekitarnya. Dimana dalam proses pengambilan keuntungan tersebut seringkali perusahaan menimbulkan kerusakan lingkungan ataupun dampak sosial lainnya.

\section{METODOLOGI}

Alur kegiatan menyeluruh pola pendampingan Pemetaan Lingkungan (Environment Scanning).

Metode pelaksanaan dilakukan dengan cara: 
1. Pengumpulan data sekunder

Data sekunder dikumpulkan untuk melihat monografi desa dan kondisi demografi kependudukan, misalnya jenis kelamin, tingkat pendidikan, jumlah keluarga, jenis pekerjaan. Selengkapnya analisis database dan survei masyarakat adalah untuk mengetahui informasi awal mengenai:

a. Sosio-demografis

b. Sosio-ekonomi

c. Sosio-budaya masyarakat

Hasil yang diharapkan meliputi:

a. Kondisi-kondisi yang menyebabkan terjadinya permasalahan sosial

b. Tingkat kebutuhan dasar

c. Kuantitas dan kualitas potensi sosial

Sehingga berdasarkan analisa data maka akan diketahui:

a. Permasalahan sosial yang menonjol

b. Permasalahan sosial yang harus segera ditangani

c. Potensi dan sumber sosial yang dapat di manfaatkan

\section{Pelaksanaan Focus Group Discussion}

FGD di lakukan untuk memperoleh kondisi pranata sosial dan interaksi yang terjadi dalam masyarakatnya, mengetahui 9 macam sarana dan prasarana yang ada di wilayah tersebut.

FGD bertujuan untuk:

a. Persiapan untuk memulai kerjasama

b. Pembentukan kemitraan

c. Melihat dan mengindentifikasi tantangan yang akan dihadapi di lapangan

d. Identifikasi kekuatan

e. Penentuan arah kegiatan

3. Survei dan Pemetaan potensi ekonomi

Survei dilakukan menggunakan instrumen kuesioner dengan menentukan responden berdasarkan jenis pekerjaan. Survei kuesioner untuk memastikan kondisi social ekonomi individu dan tingkat kesadaran penduduk untuk keluar dari kemiskinan.

Pemetaan potensi ekonomi dilakukan untuk mengindentifikasi dan memetakan:
a. Sektor perkebunan
b. Sektor perdagangan
c. Sektor jasa (pendidikan, bimbel, dokter)
d. Sektor pertanian
e. Sektor home industri/industri kreatif 
Alur kegiatan lengkap dalam kegiatan Pendampingan Environment Scanning (Pemetaan Lingkungan) idealnya terdapat dalam gambar berikut, namun untuk tahap awal, konsultan akan melakukan sampai dengan tahapan Pelaksanaan Pengkajian Metode Pendampingan atau yang dikenal dengan social mapping.

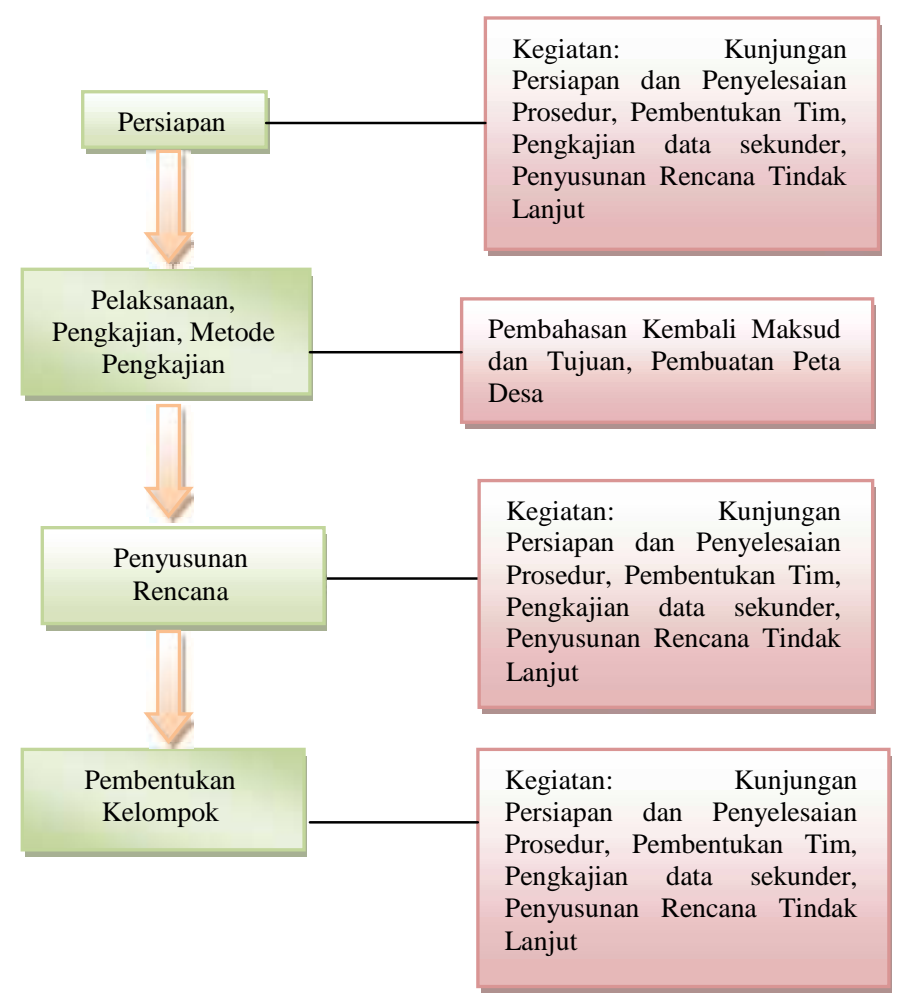

\section{HASIL DAN PEMBAHASAN}

Ada Perusahaan Tambang yang dikelola oleh pihak Swasta selain PT.BA (Bukit Asam), di antaranya PT.UN (Ulima Nitra), PT. MME (Menambang Muara Enim), PT. MBA (Multi Bangun Abadi). Perusahaan swasta ini melakukan kegiatan penambangan di lingkungan Kec.Lawang Kidul tepatnya di Desa Darmo.

Data yang diperlukan terdiri atas dua jenis, yaitu data primer dan data sekunder. Data primer berupa data persepsi dari informan penelitian, yang diterjemahkan dan diekstraksi oleh peneliti. Informan penelitian dipilih secara rekursif dari Pengurus RT di setiap lokasi penelitian. Di Desa Darmo dipilih 5 (Lima) Dusun, dengan jumlah \pm 2500 jiwa, dengan demikian secara keseluruhan terdapat $5 \mathrm{RW}$ yang menjadi informan penelitian ini. Teknik pengumpulan data yang digunakan adalah pengamatan, wawancara, dan dokumentasi.

Hasil pengamatan, wawancara dan dokumentasi selanjutnya diolah kembali oleh peneliti berdasarkan persepsi peneliti. Teknik pengamatan yang digunakan adalah teknik pengamatan Spradley (1980), yang terdiri dari; pengamatan umum, pengamatan terfokus, dan pengamatan selektif. 
Wawancara yang dilakukan adalah jenis wawancara tidak terstruktur yang sangat tergantung dari arah pembicaraan informan kunci. Pedoman wawancara yaitu salah satu pedoman wawancara yang menekankan pandangan (pendapat) atau persepsi dari informan kunci. Teknik dokumentasi digunakan untuk mendukung data yang ditemukan dalam proses pengamatan dan wawancara.

Analisis data terdiri dari komponen reduksi data, sajian data, dan penarikan kesimpulan. Empat komponen tersebut saling berinteraksi dan merupakan kegiatan siklus. Penarikan kesimpulan dilakukan peneliti dengan teknik triangulasi data.

\section{Pemetaan Masyarakat Kecamatan Lawang Kidul.}

Kecamatan Lawang Kidul adalah Kecamatan yang berbatasan langsung dengan areal perusahaan Tambang Batubara. Desa Darmo dengan luas masingmasing 435 Hektar ini, termasuk ke dalam wilayah Kecamatan Lawang Kidul Kabupaten Muara Enim.. Penduduk Desa Darmo di Tahun 2013. Mayoritas penduduk di kedua kelurahan ini adalah beragama islam

\section{Karakteristik Ekonomi}

Pendapatan masyarakat Desa Darmo, dipandang sebagian responden relatif dapat memenuhi kebutuhan sehari-hari. Sumber pencaharian utama adalah Petani dan Karyawan swasta. Sebagian masyarakat petani dapat beralih profesi menjadi karyawan tambang jika ada perekurtan tenaga kerja proyek dari perusahaanperusahaan di sekitar Desa Darmo. Para karyawan lepas ini biasanya mendapatkan upah harian ditambah dengan fasilitas makan setiap harinya.

Pemenuhan kebutuhan ekonomi secara individu berdasarkan rangkuman keterangan responden relatif cukup. Indikator paling menonjol adalah kepemilikan aset konsumsi seperti memiliki sepeda motor. Meskipun kepemilikan aset produktif relatif masih sedikit.

Rata-rata masyarakat desa darmo juga memiliki tabungan yang biasanya diperuntukan untuk tabungan di hari tua. Karakteristik ekonomi secara komunitas menunjukan kecenderungan disparitas yang cukup tinggi antar kelompok. Kondisi ekonomi antar penduduk lokal dan pendatang, atau antara karyawan perusahaan dan buruh dan petani, relatif berbeda.

Karakteristik paling menonjol dari ekonomi komunitas di Desa Darmo adalah kondisi struktur ekonomi yang lebih gemuk pada golongan menengah. Kemudian golongan kecil, dan kemudian baru golongan atas. Golongan menengah dicerminkan oleh karyawan, golongan atas dicerminkan oleh Pemilik lahan Karet dan Karyawan BUMN, dan golongan bawah dicerminkan oleh buruh dan petani karet.

Kegiatan penunjang ekonomi masyarakat, relatif tidak banyak dan tidak variatif. Hanya terdapat kelompok petani karet, dan kelompok pengajian kaum perempuan yang cukup aktif kegiatannya. Kurang variatifnya kegiatan penunjang ekonomi fisik nampaknya disebabkan karena kondisi penunjang ekonomi non fisik yang juga rendah. 
Pemanfaatan peluang usaha, inovasi dan kreatifitas masyarakat relatif rendah, sehingga kurang dapat memanfaatkan sumberdaya yang sebenarnya relatif cukup besar di desa darmo. Kondisi ini juga diperburuk dengan kurangnya perhatian aparat kecamatan dan desa. Akibatnya jika masih terdapat motivasi dari dalam diri masyarakat, cenderung tidak ditindaklajuti mengingat motivasi eksternal dipandang masyarakat hampir tidak ada.

Penunjang kegiatan ekonomi petani karet belum tersedia di Desa seperti Tempat Pelelangan karet yang dilakukan. Hanya dipergunakan sebagai tempat bertemunya penjual pembeli.

\section{Karakteristik Sosial}

Kondisi dan karakteristik sosial individu masyarakat Desa Darmo relatif cukup baik. Usia masyarakat Desa Darmo mayoritas berada pada kelompok usia produktif (40 - 50 Tahun). Rata-rata usia meninggal di kelurahan ini biasanya sekitar 65 Tahun, yang mayoritas disebabkan karena usia tua dan sakit. Jarang ditemukan orang meninggal karena sakit yang lama dan menahun.

Rata-rata usia perkawinan adalah berkisar 20 Tahun bagi perempuan, dan 23 Tahun bagi laki-laki. Meski tidak sering, namun perkawinan campur antar etnis selalu ada. Biasanya perkawinan campur lebih banyak dilakukan oleh penduduk pendatang dibanding penduduk lokal. Selain itu perkawinan campur cenderung dilakukan oleh orang-orang yang lebih berpendidikan dan domisilinya biasanya di sekitar pusat Desa Darmo. Juga domisili penduduk di sekitar desa darmo.

Mayoritas agama adalah Islam dan mayoritas etnis adalah etnis melayu. Pendidikan relatif cukup tinggi, karena rata-rata telah berpendidikan di atas SLTA.

Namun, lulusan SLTA di Desa Darmo melanjutkan pendidikan ke Perguruan Tinggi (PT), yang hanya ada di luar daerah. Lulusan SLTA yang melanjutkan ke PT biasanya adalah anak karyawan atau PNS. Sementara anak petani, dan buruh, rata-rata ikut membantu orang tua menekuni profesi yang sama dengan profesi orangtuanya. Masyarakat hampir seluruhnya memanfaatkan fasilitas kesehatan di Puskesmas dan Posyandu, jika memerlukan pelayanan kesehatan. Sedikit sekali yang menggunakan misalnya jasa dukun beranak atau pelayanan alternatif non medis. Namun, kebiasaan hidup sehat relatif cukup bagus pada keluarga karyawan atu PNS. Keluarga lainnya, relatif tidak disiplin dalam kebiasaan hidup sehat. Akibatnya kondisi di sekitar perumahan karyawan lebih bersih.

Kondisi dan karakteristik sosial secara komunitas cenderung semakin lemah. Meski adat istiadat dan nilai dan norma masih dipegang teguh, namun kesetiakawanan dan kegotong royongan sudah mulai diabaikan.

Padahal, kesetiakawanan dan kegotong royong adalah cermin dari nilai-nilai sosial. Semakin tinggi kesetiakawanan dan kegotongroyongan di implementasikan, maka semakin besar modal sosial yang dimiliki.

Adat istiadat meski tetap dipegang teguh, namun cenderung hanya pada kelompok etnisnya. Misalnya adat melayu pada kelompok etnis melayu, atau adat Jawa yang hanya diimplementasikan pada kelompok etnis Jawa. Belum 
ditemukan adat istiadat yang merupakan hasil dari proses asimilasi antar etnis. Produk hasil proses asimilasi memang memerlukan waktu yang lebih panjang untuk wilayah yang terlalu didominasi oleh hanya satu atau dua etnis saja seperti di Desa Darmo ini.

Demikian pula halnya dengan nilai-nilai dan norma, juga terpolarisasi hanya pada satu nilai dan norma agama, utamanya adalah nilai dan norma Agama Islam. Nilai dan norma Agama Islam masih sangat kuat, mengingat agama ini adalah agama mayoritas di Desa Darmo. Nilai-nilai kebenaran dan kepatutan di desa darmo, dengan demikian bagian terbesarnya adalah berdasarkan nilai dan ajaran Agama Islam. Fenomena ini dapat ditemui pada berbagai kegiatan sosial, dimana prosesi kegiatan lebih banyak mengadopsi ajaran Agama Islam.

\section{Karakteristik Budaya dan Psikologi}

Acara keagamaan sangat menonjol untuk mendorong budaya masyarakat menjadi lebih baik. Beberapa faktor lain justru kurang berperan dalam membentuk budaya di Masyarakat Desa Darmo. Acara kekeluargaan misalnya hanya melibatkan bagian terkecil dari kelompok masyarakat.

Terpolarisasinya budaya menjadi beberapa kelompok besar berdasarkan etnis menjadi penyebab lambatnya proses asimilasi di Desa Darmo. Akibatnya adalah disparitas budaya menjadi cukup jelas terlihat. Orangtua dan tokoh masyarakat berpengaruh cukup kuat dalam membentuk perilaku dan budaya masyarakat.

Hal ini linear dengan etnis dan agama mayoritas yang memandang orangtua serta tokoh masyarakat (pemuka agama) sebagai pihak yang disegani.

Etos dan disiplin kerja masyarakat Desa Darmo sebenarnya relatif tinggi. Waktu dan target kerja biasanya menjadi prioritas untuk ditunaikan. Di samping itu usaha mencapai keinginan juga sangat kuat, sehingga terkadang menggunakan semua sumberdaya yang ada untuk mencapai keinginan. Namun, terkadang masyarakat tidak bisa membedakan antara keinginan dan kebutuhan.

Masyarakat Desa Darmo kedalam masyarakat yang memiliki harga diri yang kuat. Pantang untuk dianggap lemah dan tidak berdaya, sehingga ingin selalu menunjukan kemampuan.

Refleksi dari kondisi psikologi ini adalah gaya hidup konsumeristik dan tabu untuk berhutang. Keinginan untuk dihargai dan tidak dianggap lemah juga dapat tercermin dalam hierarki aktualiasi diri. Secara berurutan hierarki keinginan Masyarakat Desa Darmo adalah;

1. Naik Haji,

2. Jabatan,

3. Harta,

4. Pendidikan.

Seseorang dianggap masyarakat sukses dan berhasil adalah jika dapat memenuhi keinginan yang urutannya paling tinggi dari hierarki keinginan. Subsidi dan bantuan baik dari pemerintah maupun BUMN bukan dinilai dari jenis dan jumlah bantuannya, tetapi dinilai dari siapa yang memberikan bantuan itu. Hal ini terkait dengan hierarki keinginan yang menyebutkan jabatan (BUMN, PNS, Legislatif) adalah hierarki tertinggi. 
Mendapat bantuan dari BUMN adalah sebuah kebanggaan karena dianggap dihargai. Sebaliknya tidak mendapatkan bantuan BUMN adalah sebuah "penghinaan" karena merasa tidak dianggap dan dihargai.Kondisi ini terlihat jelas, disaat masyarakat nelayan bekerja pada proyekproyek pembangunan di BUMN.

Meskipun upah yang diterima lebih rendah dibanding hasil melaut, namun tetap pekerjaan itu dipilih. Ada kebanggaan saat bekerja pada proyek BUMN. Kebanggaan itu menjadi topik pembicaraan saat yang bersangkutan berinteraksi dengan masyarakat lainnya di waktu senggang.

\section{Masyarakat Miskin Desa Darmo}

Masyarakat miskin di Desa Darmo ditandai dengan tingkat kesejahteraan yang berada pada kelompok 10-15\% terendah, usia 41-50 Tahun, dan status kepemilikan rumah kontrak/sewa. Sedangkan masyarakat hampir tidak miskin di Desa Darmo adalah tingkat kesejahteraannya berada pada kelompok 21-30\% terendah, usia 41-50 Tahun, dan status kepemilikan rumah milik sendiri.

Kantong kemiskinan dengan kategori sangat miskin dan miskin mayoritas berada di Kampung 4 (Dusun 4) Desa Darmo, Sementara masyarakat hampir tidak miskin mayoritas berdomisili di kampung 5 (Dusun 5)

Mengacu pada karakteristik masyarakat berdasarkan kondisi ekonomi, sosial, budaya dan psikologis, dapat dipetakan tipe masyarakat Desa Darmo yang menjadi sasaran (target group) CSR antaranya PT.UN (Ulima Nitra), PT. MME (Menambang Muara Enim), PT. MBA (Multi Bangun Abadi), yaitu:

1). Masyarakat yang cenderung tergolong ke dalamTipe I adalah masyarakat yang;

a) Berprofesi Karyawan dan PNS,

b) Mayoritas masyarakat pendatang

2). Masyarakat yang cenderung tergolong ke dalam Tipe II adalah masyarakat yang;

a) Bermata pencaharian Pemilik lahan karet

b) Berdomisili di tempat usaha atau pusat-pusat keramaian

c) Campuran masyarakat lokal dan pendatang

3). Masyarakat yang cenderung tergolong ke dalam Tipe III adalah masyarakat yang;

a) Bermatapencaharian buruh tani, dan buruh

b) Mayoritas masyarakat local.

\section{Sasaran, Jenis dan Pendekatan Program CSR}

Sekilas tentang CSR PT.UN (Ulima Nitra), PT. MME (Menambang Muara Enim), PT. MBA (Multi Bangun Abadi). Beberapa poin penting dalam desain program Corporate Social Responsibility (CSR) antaranya PT.UN (Ulima Nitra), PT. MME (Menambang Muara Enim), PT. MBA (Multi Bangun Abadi). adalah tentang substansi, Visi dan Misi, serta Payung Program CSR. CSR secara substansi adalah, cara pandang perusahaan tentang keseimbangan antara visi sosial, untuk peduli dengan masyarakat dan lingkungan sekitarnya, dan visi 
operasional untuk mencapai keuntungan (profit) yang maksimal dan menjamin kepuasan konsumen.

Visi CSR antaranya PT.UN (Ulima Nitra), PT. MME (Menambang Muara Enim), PT. MBA (Multi Bangun Abadi). adalah: "Terwujudnya harmoni perusahaan dan masyarakat menuju peningkatan kesejahteraan dan kemandirian yang berkelanjutan. Pencapaian visi ini, selanjutnya akan dicapai melalui pelaksanaan Misi CSR yaitu:

1) Mewujudkan keserasian lingkung-an hidup secara berkelanjutan.

2) Memberdayakan potensi sumberdaya menuju peningkatan kualitas hidup dan kemandirian masyarakat.

3) Meningkatkan citra positif perusahaan di kalangan stakeholders.

4) Membangun sinergi perusahaan dengan stakeholders untuk keberlanjutan operasional perusahaan.

Pencapaian Visi dan implementasi Misi CSR antaranya PT.UN (Ulima Nitra), PT. MME (Menambang Muara Enim), PT. MBA (Multi Bangun Abadi). diarahkan pada program pokok yang senantiasa menjadi payung program yaitu Pilar Program yang terdiri dari:

1) Membangun kapital manusia;

2) Penguatan ekonomi;

3) Pengembangan sinergi dan kemitraan;

4) Penguatan tatakelola organisasi;

5) pengelolaan lingkungan berkelanjutan, dan

6) peningkatan komunikasi publik.

\section{Sasaran Program CSR}

Sasaran CSR antaranya PT.UN (Ulima Nitra), PT. MME (Menambang Muara Enim), PT. MBA (Multi Bangun Abadi). idealnya adalah Masyarakat Tipe III. Pertimbangan pengambilan sasaran program CSR PKT yang fokus kepada masyarakat Tipe III, adalah:

a) Keseluruhan masyarakat telah menjadi tanggung jawab dan kewajiban Pemda Kab. Muara Enim, sehingga CSR antaranya PT.UN (Ulima Nitra), PT. MME (Menambang Muara Enim), PT. MBA (Multi Bangun Abadi). hanya mengambil sebagian saja dari seluruh sasaran masyarakat yang dimungkinkan.

b) Jenis dan bentuk program pembangunan pemerintah sulit dikreasi untuk melayani kebutuhan program masyarakat Tipe III.

c) Masyarakat Tipe III adalah golongan masyarakat yang paling mendesak untuk ditangani, namun paling jarang disentuh oleh pemerintah.

d) Pencapaian sebagian visi CSR PKT, yaitu; "kemandirian yang berkelanjutan" menjadi lebih besar kemungkinan tercapainya, mengingat masyarakat Tipe III inilah yang paling rendah tingkat kemandiriannya. Masyarakat Tipe III, selanjutnya dikelompokkan kembali menjadi; sangat miskin, miskin dan hampir tidak miskin. Di antara tiga kelompok masyarakat miskin (Tipe III) ini, kembali program CSR PKT lebih difokuskan pada kelompok masyarakat sangat miskin dan miskin. Sementara pada kelompok masyarakat hampir tidak miskin, sebaiknya diarahkan untuk ditangani Pemda Kabupaten Muara Enim. 


\section{Jenis Program CSR}

Idealnya jenis program yang dibuat adalah program yang dominan dilakukan oleh program nonfisik. Karena jenis program nonfisik inilah yang paling dibutuhkan oleh kelompok Masyarakat Tipe III. Minimal jenis program yang dibuat adalah jenis program gabungan (mix). Program Mix adalah jenis program nonfisik yang disertai dengan dukungan program fisik. Dengan demikian masih tetap dimungkinkan bagi CSR antaranya PT.UN (Ulima Nitra), PT. MME (Menambang Muara Enim), PT. MBA (Multi Bangun Abadi). untuk tetap membuat program fisik, namun tujuannya untuk mendukung program nonfisik.

Mengacu kepada payung (pilar) program yang telah ditetapkan pada desain program CSR PKT 2011-2016, tercatat terdapat 36 program. Dari ke 36 program tersebut, jika digolongkan terdapat 79 program nonfisik (51.63\%), 46 program fisik (30.07\%), dan 28 program mix (18.3\%). Pengelompokkan program CSR ini, arah pelaksanaan program CSR antaranya PT.UN (Ulima Nitra), PT. MME (Menambang Muara Enim), PT. MBA (Multi Bangun Abadi). secara kuantitas sudah benar.

Kesimpulan ini diambil melihat dominasi program telah berupa program nonfisik, jika dibanding program fisik maupun program mix. Meskipun demikian, dominasi program nonfisik sebaiknya diperbesar melalui berbagai kreasi program, minimal adalah program mix.

Dominasi program nonfisik, idealnya juga memperhatikan jumlah dana yang disalurkan untuk itu. Jika anggaran yang digunakan untuk melaksanakan 25 program nonfisik lebih besar dari pada penyelenggaraan 9 program fisik, maka jenis program CSR antaranya PT.UN (Ulima Nitra), PT. MME (Menambang Muara Enim), PT. MBA (Multi Bangun Abadi). telah sesuai dengan sasaran. Jika sebaliknya, maka jenis program ini patut ditelusuri lebih jauh. Apakah program nonfisik konsisten dengan sasaran masyarakat Tipe

III atau tidak. Jika konsisten, maka antara jenis dengan sasaran program telah sesuai.

Sebaliknya, jika tidak konsisten, maka komitmen untuk menentukan sasaran

harus ditinjau ulang.

\section{Pendekatan Program CSR PKT}

Pendekatan program pada umumnya terdiri atas tiga kelompok besar, yaitu pendekatan personal, kelompok, dan komunitas. Pendekatan personal (Mikro) adalah pendekatan yang memungkinkan perusahaan (change agent) untuk berinteraksi langsung dengan sasaran program (target group). Pendekatan kelompok (Mezo) adalah pendekatan yang masih memungkinkan interaksi antara perusahaan dengan sasaran, namun dengan intensitas yang terbatas. Pendekatan komunitas (Makro) adalah pendekatan yang tidak memerlukan hubungan interaksi antara perusahaan dengan sasaran.

Mengacu kepada tiga pendekatan program ini, maka idealnya pendekatan CSR antaranya PT.UN (Ulima Nitra), PT. MME (Menambang Muara Enim), PT. MBA (Multi Bangun Abadi) adalah pendekatan yang didominasi oleh pendekatan 
personal dan pendekatan kelompok. Beberapa pertimbangan penggunaan kedua pendekatan program ini adalah:

a) Visi CSR antaranya PT.UN (Ulima Nitra), PT. MME (Menambang Muara Enim), PT. MBA (Multi Bangun Abadi) adalah Harmonisasi dan Kemandirian.

b) Sasaran program CSR antaranya PT.UN (Ulima Nitra), PT. MME (Menambang Muara Enim), PT. MBA (Multi Bangun Abadi) adalah mayoritas masyarakat Tipe III, yang paling rendah tingkat kemandiriannya.

c) Meski harmonisasi juga menjadi Visi CSR antaranya PT.UN (Ulima Nitra), PT. MME (Menambang Muara Enim), PT. MBA (Multi Bangun Abadi)., namun potensi konflik besar terjadi pada masyarakat Tipe I, yang sudah banyak ditangani oleh Pemda Kab. Muara Enim dengan program fisiknya.

d) Jenis program CSR antaranya PT.UN (Ulima Nitra), PT. MME (Menambang Muara Enim), PT. MBA (Multi Bangun Abadi). lebih banyak didominasi oleh program nonfisik.

Masyarakat Tipe III adalah sasaran CSR antaranya PT.UN (Ulima Nitra), PT. MME (Menambang Muara Enim), PT. MBA (Multi Bangun Abadi). yang mendesak untuk segera ditangani. Mengingat karakteristik masyarakat Tipe III yang sangat rendah kemandiriannya, maka program yang diperlukan adalah program yang banyak didominasi oleh program nonfisik. Program nonfisik dapat dapat dilaksanakan dengan efektif jika dilakukan dengan pendekatan personal atau pendekatan kelompok. Mengacu pada hasil pemetaan dan deskripsi program yang telah dilakukan CSR antaranya PT.UN (Ulima Nitra), PT. MME (Menambang Muara Enim), PT. MBA (Multi Bangun Abadi), maka dapat dikatakan bahwa program CSR antaranya PT.UN (Ulima Nitra), PT. MME (Menambang Muara Enim), PT. MBA (Multi Bangun Abadi). masih belum serasidengan jenis program, sasaran dan pendekatannya. Penyebab tidak konsistennya program dengan sasaran dan pendekatan CSR disebabkan karena pemetaan masyarakat sasaran belum dilakukan oleh CSR antaranya PT.UN (Ulima Nitra), PT. MME (Menambang Muara Enim), PT. MBA (Multi Bangun Abadi)..

Penentuan sasaran, jenis dan pendekatan program, dapat menunjukan arah dalam pelaksanaan CSR antaranya PT.UN (Ulima Nitra), PT. MME (Menambang Muara Enim), PT. MBA (Multi Bangun Abadi)..

Selain itu dapat memberikan peluang program CSR bersinergi dengan program pembangunan Pemerintah Kabupaten Muara Enim. Tumpang tindih program, duplikasi sasaran program, dan ketidaktepatan antara sasaran, jenis dan pendekatan, probabilitanya akan menjadi lebih kecil.

\section{KESIMPULAN}

Program CSR antaranya PT.UN (Ulima Nitra), PT. MME (Menambang Muara Enim), PT. MBA (Multi Bangun Abadi). masih belum digagas secara serasi dengan sasaran dan pendekatan program. Konsistensi antara jenis program dengan sasaran dan pendekatan yang digunakan, menjadi titik lemah program. 
Penyebabnya adalah pemetaan masyarakat sebagai dasar penentuan jenis program, sasaran, dan pendekatan yang digunakan masih belum dilakukan.

Masyarakat Desa Darmo dapat dikluster menjadi tiga tipe, yaitu;

a) Masyarakat tipe I yang bercirikan karyawan dan PNS, berdomisili di perumahan karyawan dan perumahan umum, dan mayoritas masyarakat pendatang.

b) Masyarakat tipe II yang bercirikan pedagang dan pengusaha, berdomisili di tempat usaha dan pusat keramaian, dan campuran masyarakat lokal dan pendatang.

c) Masyarakat tipe III yang bercirikan nelayan, petani dan buruh, berdomisili di pesisir dan mengelompok berdasarkan etnis, dan mayoritas masyarakat lokal. Masyarakat Tipe III merupakan sasaran CSR PT. antaranya PT.UN (Ulima Nitra), PT. MME (Menambang Muara Enim), PT. MBA (Multi Bangun Abadi). yang mendesak untuk segera ditangani. Mengingat karakteristik masyarakat Tipe III yang sangat rendah kemandiriannya, maka program yang diperlukan adalah program yang banyak didominasi oleh program nonfisik. Program nonfisik dapat dilaksanakan dengan efektif jika dilakukan dengan pendekatan personal atau pendekatan kelompok.Memfokuskan kegiatan dan program CSR pada kelompok masyarakat tipe III ini, memberikan peluang keberhasilan yang lebih besar sekaligus dapat bersinergi dengan program pembangunan fisik yang dilaksanakan Pemerintah Kabupaten Muara Enim. Dengan demikian probabilita terjadinya tumpang tindih program, duplikasi program dan ketidaktepatan sasaran, jenis dan pendekatan antara program CSR PT.UN (Ulima Nitra), PT. MME (Menambang Muara Enim), PT. MBA (Multi Bangun Abadi dan Pemerintah Kabupaten Muara Enim akan menjadi lebih kecil.

\section{SARAN}

Salah satu tujuan perusahaan dalam melaksanakan program CSR adalah meningkatkan citra positif melalui hubungan harmonis antara perusahaan dan masyarakat. Citra positif ini dapat dicapai baik dalam jangka pendek maupun jangka panjang. Hasil

penelitian mengarah pada poin penting dimana dalam melaksanakan kegiatan/program CSR, PT.UN (Ulima Nitra), PT. MME (Menambang Muara Enim), PT. MBA (Multi Bangun Abadi). Selaku pihak perencana dan pelaksana program seyogyanya mempertimbangkan karakteristik masyarakat sasaran CSR. Karakteristik masyarakat dapat menunjukkan arah untuk dapat mengidentifikasi kebutuhan dan keinginan masyarakat.

Pilihan program CSR yang bertujuan meningkatkan citra perusahaan dalam jangka pendek biasanya identik dengan kegiatan yang didasarkan pada keinginan masyarakat. Bukan hal yang buruk, tetapi konsekuensinya perusahaan akan membuat masyarakat merasa tergantung pada bantuan sehingga jika tujuan perusahaan adalah untuk meningkatkan kemandirian masyarakat maka hal tersebut akan sulit tercapai. Lain halnya jika program-

program dalam CSR perusahaan didasarkan pada kebutuhan masyarakat. Hal tersebut akan memberikan dampak positif terhadap tingkat kemandirian karena 
berarti perusahaan, melalui program CSR, memberikan dorongan dan fasilitas untuk meningkatkan kemampuan

mereka untuk menaikkan derajat kehidupan mereka sendiri. Satu-satunya masalah adalah jika program CSR perusahaan hanya concernpada peningkatan kemandirian masyarakat maka hal ini akan menjadi bumerang pada citra postitif perusahaan dalam jangka pendek

\section{DAFTAR PUSTAKA}

\section{Jurnal:}

Anis Fitriani,. Pengaruh Kinerja Lingkungan dan Biaya Lingkungan Terhadap Kinerja Keuangan pada BUMN, Fakulas Ekonomi. Universitas Negeri Sriwijaya. Jurnal Ilmu Manajemen. Vol. 1 No. 1 Tahun 2013.

Hadi, Nor 2011. Interaksi Tanggungjawab Sosial, Kinerja Sosial, Kinerja Keuangan dan Luas Pengungkapan Sosial (Uji Motif di Balik Social Responsibility Perusahaan Go publik di Indonesia). Maksimum, Volume 1 No. 2

Hartanti, Dwi. 2004. Pengaruh Kinerja Lingkungan Hidup Perusahaan Serta Sistem Manajemen Lingkungan Hidup Perusahaan Terhadap Kinerja Keuangan Perusahaan. Economics Business \& Accounting Review, Edisi III/ September-Desember.

Irwan Gani dkk., Pemetaan Masyarakat sebagai target group program CSR PT PKT Bontang, FE Universitas Mulawarman. Sosiohumaniora, Volume 17 No.1, Maret 2015. Hal 28- 34.

\section{Buku:}

Bates, P. 2011. Taking a Lead in Promoting Choice, Control and Valued Opportunities for Socially Excluded and Vulnerable People. National Development Team for Inclusion, United Kingdom. Sumber: http: // www.iriss.org.uk/resources/taking-lead-promoting-choice control-and valued opportunities socially-excluded-and-vulner

Ilmu Ekonomi, Universitas Hasanuddin, Makassar. Geertz C., 1973. The Interpretation of Culture, New York : Basic Books

Kotler, Philip. 2005. Manajemen pemasaran, (Edisi kesebelas). PT. Indeks Kelompok Gramedia. Jakarta

McMurtry, SL., et al. 1993. Strategic Choices Made by Nonprofit Agencies Serving Low Paying Clients. Community Organization and Social Administration: Advances, Trends and Emerging Principles. New York: Haworth Press 
Overweel, Jeroen A. 2008. The Marind in A Changing Environment.Irian Jaya: YAPSEL. Indonesia.

Roaf, Virginia. 2005. Community Mapping: A Tool for Community Organizing. London: Water Aid, http:// www.wateraid.org/ /media/Publications / community mapping-programme-partner-guidelines. pdf

\section{Skripsi/Tesis/Disertasi:}

Gani, Irwan., 2010. Permasalahan Pemberdayaan Masyarakat Wilayah Pesisir (Studi Kasus di Kecamatan Anggana Kabupaten Kutai Kartanegara). Disertasi.

Sumardiyono, Eko.2007.Evaluasi Pelaksanaan Community Development dalam Perolehan PROPER hijau. (tesis) http://eprints.undip.ac.id/17349. 